\title{
Colostrum and milk pasteurization improve health status and decrease mortality in neonatal calves receiving appropriate colostrum ingestion
}

\author{
Ramon Armengol* and Lorenzo Fraile ${ }^{*} \dagger^{1}$ \\ *Departament de Producció Animal, ETSEA, University de Lleida, Lleida 25198, Spain \\ †Agrotecnio Center, Lleida 25198, Spain
}

\begin{abstract}
The objective of the study was to evaluate if on-farm heat treatment of colostrum and bulk tank milk can improve calf health status and morbidity and mortality rates during the first $21 \mathrm{~d}$ of life in neonatal Holstein calves receiving appropriate colostrum ingestion. A total of 587 calves were randomly assigned to 2 groups of males and females over 18 mo. The nonpasteurized group ( $\mathrm{n}=287,143$ males and 144 females) was fed frozen $\left(-20^{\circ} \mathrm{C}\right)$ colostrum $(6-8 \mathrm{~L}$ during the first $12 \mathrm{~h}$ of life) that was previously reheated up to $40^{\circ} \mathrm{C}$. They were also fed refrigerated $\left(4^{\circ} \mathrm{C}\right)$ raw milk from the bulk tank that was also reheated up to $40^{\circ} \mathrm{C}(1.8 \mathrm{~L}$ every $12 \mathrm{~h})$. The pasteurized group $(\mathrm{n}=300,150$ males and 150 females) was also fed colostrum and milk, but both were pasteurized before freezing. Blood samples were drawn from all calves to obtain serum at 2 to $5 \mathrm{~d}$ of life. Serum total protein $(\mathrm{g} / \mathrm{dL})$ was determined using a commercially available refractometer. Colostrum and milk underwent routine bacteriological analysis to determine total plate counts $(\mathrm{cfu} / \mathrm{mL})$ and total coliform counts $(\mathrm{cfu} / \mathrm{mL})$. All the calves underwent clinical examination every $24 \mathrm{~h}$ during the first $21 \mathrm{~d}$ of life. Every day, calves were clinically diagnosed either as being healthy or suffering from respiratory disease, neonatal calf diarrhea, or suffering other diseases. On-farm heat treatment for colostrum and milk reduced total plate counts and total coliform counts between 1 and $2 \log _{10}$. Pasteurization of colostrum and milk significantly decreased the morbidity and mortality (5.2 and $2.8 \%$ ) in comparison with calves receiving nonpasteurized colostrum and milk (15.0 and 6.5\%), respectively, during the first $21 \mathrm{~d}$ of life, even in animals receiving appropriate colostrum ingestion.
\end{abstract}

Key words: on-farm heat treatment, colostrum, milk, health status

Received December 6, 2015.

Accepted February 11, 2016.

${ }^{1}$ Corresponding author: lorenzo.fraile@prodan.udl.cat

\section{INTRODUCTION}

Passive immunity is the only source of early immunity for calves due to the inability of bovine placenta to transmit maternal immunoglobulins to the fetus (Richter and Götze, 1993; Baintner, 2007). Thus, it is compulsory to acquire these natural defenses by colostrum ingestion. In this sense, the immune status of calves during the preweaning period depends directly on the quality and quantity of colostrum ingested during the first hours of life (Heinrichs and Elizondo-Salazar, 2008). The gold standard method accepted to evaluate passive transfer is a direct measurement of IgG concentration through radial immunodiffusion. Failure of passive transfer appears if the calf serum IgG concentration is less than $10 \mathrm{mg} / \mathrm{mL}$ when sampled between 24 and 48 h of age (Weaver et al., 2000; Godden, 2008), because a value below $10 \mathrm{mg} / \mathrm{mL}$ is a risk factor for developing diseases during the neonatal period (Godden, 2008). Unfortunately, radial immunodiffusion is not useful as an on-farm method. Evaluation of serum total proteins (STP) by refractometry is widely used by veterinarians and producers to evaluate adequate passive transfer of immunoglobulin in calves (Tyler et al., 1996); this is because the correlation between STP and $\operatorname{IgG}$ in blood is very good the first days of life, considering that IgG is the most abundant protein ingested through colostrum (Calloway et al., 2002). Thus, a value of STP between 5.0 and $6.0 \mathrm{~g} / \mathrm{dL}$ is considered to prevent failure of passive transfer after colostrum intake (Donovan et al., 1998; Windeyer et al., 2014). Moreover, a cut-off for STP of $5.2 \mathrm{~g} / \mathrm{dL}$ is accepted to guarantee the equivalent threshold value of $10 \mathrm{mg} / \mathrm{mL}$ of IgG in calf serum (Tyler et al., 1996; Calloway et al., 2002; Windeyer et al., 2014).

An appropriate colostrum ingestion program begins feeding the calf within 4 to $6 \mathrm{~h}$ after birth and has to ensure at least 4 to $5 \mathrm{~L}$ of colostrum intake during the first $8 \mathrm{~h}$ of life. This protocol allows high blood levels of circulating maternal immunoglobulins in 48-h-old calves until their immune system becomes fully functional, at 3 to 6 wk of age (Heinrichs and ElizondoSalazar, 2008). In any case, failure of passive transfer 
can occur and the incidence of respiratory or digestive disease may increase in these animals (Virtala et al., 1999; Godden et al., 2012; Pardon et al., 2015). As a consequence, cost for treatment of bovine respiratory disease (BRD) and neonatal calf diarrhea (NCD) and death rates due to both diseases may increase during the first $21 \mathrm{~d}$ of life (Meganck et al., 2014; Windeyer et al., 2014). Additionally, management of milk, buckets and sucklers, as well as timing at feeding and quantity of milk are also important factors to ensure a good health status of calves and good production parameters in the first $21 \mathrm{~d}$ of life (Wells et al., 1996). A good colostrum feeding protocol should also avoid bacterial contamination (Meganck et al., 2014) through a strict hygiene management of buckets and sucklers, because bacteria in colostrum may interfere with passive absorption of colostral antibodies into the calf's circulation (James et al., 1981). Moreover, it has been described that colostrum and milk can contain pathogens such as Mycobacterium avium ssp. paratuberculosis (Streeter et al., 1995; Sweeney, 1996), Mycoplasma spp. (Butler et al., 2000; Stabel et al., 2004), Escherichia coli, and Salmonella spp. (Smith et al., 1989; Spier et al., 1991; Stabel et al., 2004). Fortunately, pasteurization is a good way to decrease the bacterial load in colostrum, but heat treatment must avoid colostrum denaturalization and an increase in its viscosity. Previous studies observed that the conventional pasteurizing protocol for milk may alter colostrum characteristics (Meylan et al., 1996; Godden et al., 2003). It has been established that heating colostrum at $60^{\circ} \mathrm{C}$ for 30 to 60 min can be a good treatment to maintain colostrum quality (McMartin et al., 2006; Heinrichs and Elizondo-Salazar, 2008) and significantly reduce important pathogens that can contaminate it, such as Listeria monocytogenes, E. coli O157:H7, Salmonella enteritidis, and $M$. avium ssp. paratuberculosis (Stabel et al., 2004; Godden et al., 2006).

Animals fed on-farm pasteurized colostrum and waste milk showed higher ADG, a lower prevalence of pneumonia and diarrhea, and a lower mortality rate when compared with calves fed with nonpasteurized colostrum and waste milk (Jamaluddin et al., 1996; Godden et al., 2005). However, the experimental design used in these studies did not allow determination of the effect of colostrum and milk pasteurization on the health status and mortality of calves when high levels of colostrum ingestion were guaranteed. The objective of the present study was to evaluate if on-farm pasteurization of raw colostrum and bulk tank milk could improve the health status, reduce neonatal illness, and decrease death rates during the first $21 \mathrm{~d}$ of life in calves receiving appropriate colostrum ingestion monitored through a refractometer.

\section{MATERIALS AND METHODS}

\section{Animals and Farm}

The study was carried out in a dairy housing an average of 330 lactating Holstein cows with an average production of $11,100 \mathrm{~kg}$ of milk $(3.6 \%$ fat and $3.3 \%$ protein) by cow. This farm was located in Lleida (northeast Spain). Cows were milked 3 times daily (at 0400, 1200, and $2000 \mathrm{~h}$ ). Milk from each cow was sampled and analyzed for milk quality (fat, protein, and lactose concentration) and SCC by technicians of the Central Laboratory for Milk Recording (ALLIC, Catalonia, Cabrils, Spain) once a month. This farm is positive for bovine herpesvirus type I (BoHV-1) and bovine viral diarrhea virus (BVDV), and these viruses can play an important role as respiratory pathogens in calves. Cows and heifers were vaccinated against BoHV-1, BVDV, bovine respiratory syncytial virus, and influenza virus (Hiprabovis IBR Marker live and Hiprabovis BVD balance, Hipra, Girona, Spain) every 6 mo. Vaccination was carried out by veterinarians and a single-use needle was used per each cow. Additionally, the farm was under an official eradication program of BoHV1 using glycoprotein E (gE)-deleted marked vaccine. Moreover, individual serology was carried out once a year to detect infected (gE-positive) animals. Control of BVDV is also very strict, with vaccination and identification of persistently infected animals through PCR. Finally, bulk tank milk sampling was carried out every 4 mo by PCR for BVDV and ELISA gE for BoHV-1 detection. Cows were moved 3 wk before calving to a facility where parturition in groups occurred (5-10 cows). Newborn calves were removed from the pen immediately after calving to avoid suckling. First milking of colostrum was obtained between 30 to 90 min after calving. Calves were not fed with colostrum coming from their dam but were fed frozen colostrum, whether heat treated or not, from a single cow, because mixing colostrum from different cows was not allowed. Colostrum bags were stored frozen an average of $6 \mathrm{~d}$ before calves received it. Only colostrum with a specific gravity $\geq 1,065$ was considered suitable for feeding calves (Fleenor and Stott, 1980).

A total of 587 female and male calves were randomly assigned to 2 groups considering ear tag number as allocating criteria (even and odd numbers) for 18 mo. As inclusion criteria, animals had to be singletons born from a normal parturition and with STP values $\geq 5.8$ $\mathrm{g} / \mathrm{dL}$. This value was chosen taking previous studies into account. Although a cut-off for STP of $5.2 \mathrm{~g} / \mathrm{dL}$ is accepted by some authors as good enough to guarantee the equivalent threshold value of $10 \mathrm{mg} / \mathrm{mL}$ of IgG in calf serum (Tyler et al., 1996; Calloway et al., 


\begin{tabular}{|c|c|c|c|}
\hline $\begin{array}{l}\cdot \text { - 1st bag colostrum } \\
\text { (ad libitum) } \\
\cdot \text { Max 4 L. }\end{array}$ & $\begin{array}{l}\text { - Finish 1st bag colostrum } \\
\text { - Plus } 2 \text { nd bag colostrum ad } \\
\text { libitum. Maximum } 4 \mathrm{~L} \text {. }\end{array}$ & $\begin{array}{l}\text { - Finish 2nd bag colostrum. } \\
\text { - Objective: calf has to drink 6- } \\
8 \text { L of colostrum in } 12 \text { hours. }\end{array}$ & -1.3-2.3 L. Bulk tank milk. \\
\hline & & & \\
\hline Calving-3 hour & 6-8 hour & $8-12$ hour & Every 12 hours \\
\hline
\end{tabular}

Figure 1. Colostrum and milk feeding protocol of the study farm.

2002; Windeyer et al., 2014), others observed slight improvements in mortality and BRD morbidity rates during the calf life with STP values of 6.0 (Donovan et al., 1998) and $5.7 \mathrm{~g} / \mathrm{dL}$, respectively (Windeyer et al., 2014). Thus, we considered an STP value of 5.8 $\mathrm{g} / \mathrm{dL}$ to undoubtedly be associated with appropriate colostrum ingestion. Blood samples were drawn from all calves at 2 to $5 \mathrm{~d}$ of life and serum was obtained. Serum total protein $(\mathrm{g} / \mathrm{dL})$ was determined using a commercially available refractometer (AtagoMastersur/NE, Atago U.S.A. Inc., Bellevue, WA) at room temperature $\left(20^{\circ} \mathrm{C}\right)$. If the value obtained was higher than $7.5 \mathrm{~g} / \mathrm{dL}$, hematocrit was checked to determine if dehydration could cause a misreading. Dehydrated animals were excluded from the study

Calves were housed individually, straw bedded, and following calving time order. If an animal died, straw of the house was removed, walls and floor were cleaned with high pressure water and soap, disinfected with Kenocox (CID Lines, Ark Animal Care Ltd., Newbridge, Ireland), and the house was not used to allocate another newborn calf at least during a 15-d wash-out period. Feeding of the animals as well as colostrum and milk management was always carried out by the same employee except for one day a week (Saturday) and two 15 -d periods of vacation when these duties were carried out by the farmer. Colostrum and milk were always provided with nipple buckets, cleaned after every use, and disinfected with chlorhexidine between feedings. The feeding protocol guaranteed an ingestion of 6 to 8 $\mathrm{L}$ of colostrum by the calf during the first $12 \mathrm{~h}$ of life (Figure 1). Afterward, calves were fed an average of 1.8 L (1.3-2.3 L) of milk from the bulk tank (pasteurized or not) every $12 \mathrm{~h}$ (0800 and $2000 \mathrm{~h}$ ).Calves assigned to the nonpasteurized group (NP; even numbers; $\mathrm{n}=287$, 143 males and 144 females) were fed frozen $\left(-20^{\circ} \mathrm{C}\right)$ colostrum that was previously reheated to $40^{\circ} \mathrm{C}$. They were then fed refrigerated $\left(4^{\circ} \mathrm{C}\right)$ raw milk from the bulk tank that was also reheated to $40^{\circ} \mathrm{C}$. Calves assigned to the pasteurized group ( $\mathbf{P}$; odd numbers; $\mathrm{n}=300$, 150 males and 150 females) were under a similar feeding protocol, but both colostrum and milk had been pasteurized before freezing (Figure 2). All calves were allowed fresh water and dry food ad libitum from d 2 onwards.

\section{Colostrum and Milk Management}

Colostrum immunoglobulin concentration was measured on-farm at $21^{\circ} \mathrm{C}$ with a colostrometer (Biogenics, Florence, OR) through specific gravity. Only colostrum with density $\geq 1,065$ was used. Colostrum was stored in 4-L aluminum bags identified with the cow number (Perfect Udder 4, Dairy Tech Inc., Greeley, CO). Colostrum of the $\mathrm{P}$ group was heat-treated at $60^{\circ} \mathrm{C}$ for 60 min using a commercial on-farm batch pasteurization system (DT Silver, Dairy Tech Inc.). The temperature was subsequently lowered to $37^{\circ} \mathrm{C}$ and bags were frozen at $-20^{\circ} \mathrm{C}$. Afterward, colostrum was heated to $40^{\circ} \mathrm{C}$ before feeding the calves (Figure 2). Bulk tank milk for the $\mathrm{P}$ group was heat-treated at $63^{\circ} \mathrm{C}$ for 30 min using a commercial on-farm batch pasteurization system (Urban MilkShuttle Pasteur, Urban Gmbh \& Co, Wüsting, Germany) and then cooled down to $40^{\circ} \mathrm{C}$ before feeding the calves (Figure 2). Timing and temperatures used for pasteurization were strictly followed according to the manufacturer's instructions and have been used in other studies (Johnson et al., 2007). Paired colostrum and milk samples, assigned to the NP and P groups, were collected just before feeding the calves at $40^{\circ} \mathrm{C}$. They underwent routine bacteriological analysis to determine total plate counts (TPC; $\mathrm{cfu} / \mathrm{mL}$ ) and total coliform counts (TCC; cfu/mL) as previously described by Jayarao et al. (2004).

\section{Health Monitoring of Calves}

All calves underwent a clinical examination every 24 $\mathrm{h}$ during the first $21 \mathrm{~d}$ of life. For each animal, rectal temperature, breathing rate, consistency of the feces, attitude, and navel were checked. Calves that showed clinical signs of disease were allocated to 3 different categories. The first group included calves that were clinically diagnosed with BRD. Calves were included in this category when at least 2 of the following clinical signs were observed: inducible cough on tracheal mas- 
sage, abnormal sounds on respiratory tract auscultation, high rectal temperature $\left(>39.5^{\circ} \mathrm{C}\right)$ with increased respiratory rate, serous nasal discharge, coughing, and hyporexia or anorexia (Virtala et al., 1999). The second group included calves with NCD, which was clinically diagnosed using a score from 1 to 4 based on consistency of the feces up to $\mathrm{d} 2$ of life $(1=$ solid; $2=$ semisolid; $3=$ liquid feces; $4=$ watery). Animals with a score of 3 or 4 were considered to have NCD (Larson et al., 1977). The third group included calves suffering from nonrespiratory, nondigestive diseases, and they were assigned to this group when any of the following clinical signs were observed: trauma, congenital disease, hypothermia $\left(<37.5^{\circ} \mathrm{C}\right.$; Berchtold, 2009), neurological signs, weakness, reluctance to stand, difficulty in suckling or absence of suckling reflex, swollen joints, cloudy eyes or omphalitis, and fever $\left(>39.5^{\circ} \mathrm{C}\right)$ in the absence of respiratory or digestive signs.

Clinical examination and establishment of curative treatment for sick animals was carried out by the same veterinarians (the 2 authors of the present study) for both experimental groups to avoid any bias. A necropsy was performed on dead animals and causes of death were divided into 3 groups based on the main system affected. Thus, a respiratory cause (BRD) was established if the lung was consolidated, fibrin was noted on pleural surfaces, or emphysema, atelectasis, or tracheitis was observed. A digestive cause (NCD) was established if lesions (enteritis and fluid content) were noted in the digestive tract. Cause of death was established as other if lesions were observed in systems other than respiratory or digestive.

\section{Statistical Analysis}

All statistical analyses were carried out using the SAS system V.9.1.3 (SAS institute Inc., Cary, NC). For all analyses, the individual calf was used as the experimental unit. The significance level was set at 0.05 with statistical tendencies reported when $P<0.10$. The treatment variable was the pasteurization process (NP and $\mathrm{P}$ ) and the outcome variables were its effect on TPC and TPP in colostrum and on the health of the calves (disease or death). The variables included in the statistical analyses were classified as categorical [pasteurization status $(\mathrm{NP} / \mathrm{P})$, illness (yes/no), death (yes/no) and cause of death (BRD, NCD, and other), or continuous (STP, TPC, and TPP)]. Shapiro-Wilk
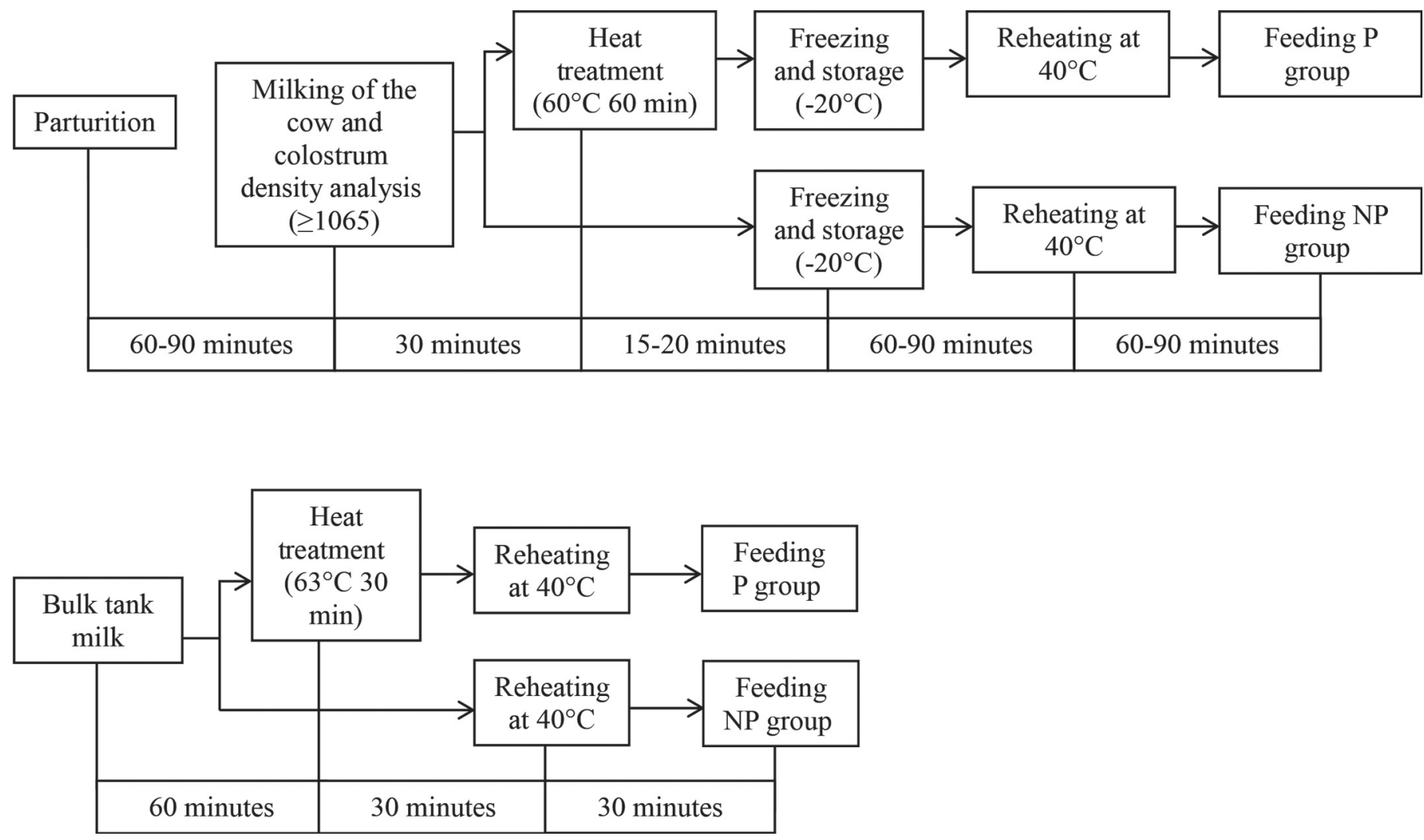

Figure 2. Processing of colostrum and bulk tank milk for calves fed pasteurized colostrum and milk (P group) and calves fed nonpasteurized colostrum and milk (NP group). 
Table 1. Effect of heat treatment of colostrum and milk on STP levels, mortality and morbidity rates, and cause of illness and death in 21-d-old Holstein calves fed with raw (NP group) and pasteurized (P group) colostrum and milk

\begin{tabular}{|c|c|c|c|}
\hline \multirow[b]{2}{*}{ Parameter } & \multicolumn{2}{|c|}{ Treatment group } & \multirow[b]{2}{*}{$P$-value } \\
\hline & $\begin{array}{l}\text { NP group } \\
(\mathrm{n}=287)\end{array}$ & $\begin{array}{l}\mathrm{P} \text { group } \\
(\mathrm{n}=300)\end{array}$ & \\
\hline$\overline{\mathrm{STP}^{1}(\mathrm{~g} / \mathrm{dL})}$ & $7.27^{\mathrm{a}}(5.8-9.2)$ & $7.34^{\mathrm{a}}(5.8-9.0)$ & 0.12 \\
\hline Mortality (\%) & $6.5^{\mathrm{a}}$ & $2.8^{\mathrm{b}}$ & $<0.001$ \\
\hline \multicolumn{4}{|c|}{ Distribution of mortality (\%) } \\
\hline $\mathrm{BRD}^{2}$ & 36.6 & 38.9 & 0.80 \\
\hline $\mathrm{NCD}^{3}$ & 43.9 & 33.3 & 0.50 \\
\hline Other & 19.5 & 27.8 & 0.55 \\
\hline Morbidity & $15.0^{\mathrm{a}}$ & $5.2^{\mathrm{b}}$ & $<0.0001$ \\
\hline \multicolumn{4}{|c|}{ Distribution of morbidity } \\
\hline BRD & 40.9 & 43.3 & 0.82 \\
\hline NCD & 39.1 & 35.7 & 0.70 \\
\hline Other & 20.0 & 21.0 & 0.90 \\
\hline
\end{tabular}

${ }_{\mathrm{a}, \mathrm{b}}$ Values within a row with different superscript letters are significantly different.

${ }^{1} \mathrm{STP}=$ serum total protein. Reported values reflect mean and range in parentheses.

${ }^{2} \mathrm{BRD}=$ bovine respiratory disease

${ }^{3} \mathrm{NCD}=$ neonatal calf diarrhea.

and Levene tests were used to evaluate the normality of the distribution of the continuous variables and the homogeneity of variances, respectively. To study the association between pasteurization status with the continuous non-normally distributed variables (TPC and TPP), the Wilcoxon test (with the Mann-Whitney Utest to compare each pair of values) was used, whereas an ANOVA test (with Student's t-test to compare each pair of values) was used to analyze the association between continuous normally distributed variables (STP). Contingency tables (Chi-square or Fisher exact tests) were used to assess the association between categorical variables. Finally, conditional logistic regression was used to estimate the univariate odds ratios (OR) and $95 \%$ confidence intervals for death and illness with pasteurization. A multivariate logistic regression analysis was also carried out to decipher the effect of STP and pasteurization and its interaction on death and illness.

\section{RESULTS}

\section{Descriptive Statistics of the Results}

Average serum total protein was 7.27 and $7.34 \mathrm{~g} / \mathrm{dL}$ for the NP and P groups, respectively. In both cases, the lowest value observed was $5.8 \mathrm{~g} / \mathrm{dL}$ and the maximum value observed was 9.2 and $9 \mathrm{~g} / \mathrm{dL}$ for the NP and $\mathrm{P}$ groups, respectively. For the NP and $\mathrm{P}$ groups, the coefficient of variation was $7.8 \%$ (Table 1 ). Regarding bacterial load, TPC and TCC were always higher in colostrum than in milk (Table 2).

Morbidity was 15 and $5.2 \%$ for the NP and P groups, respectively, and the prevalence of $\mathrm{BRD}, \mathrm{NCD}$, and other causes was 40.9, 39.1, and $20 \%$ for the NP group and $43.3,35.7$, and $21 \%$ for the $\mathrm{P}$ group, respectively (Table 1). Mortality was 6.5 and $2.8 \%$ for the NP and P groups, respectively, and the cause of death associated with BRD, NCD, and other causes was 36.6, 43.9, and $19.5 \%$ for the NP group and $38.9,33.3$, and $27.8 \%$ for the $\mathrm{P}$ group, respectively (Table 1 ).

\section{Effect of Heat Treatment on STP and Bacterial Counts}

Mean TPC and TCC were significantly lower in pasteurized colostrum and milk $(P<0.001$ in all cases $)$ than in nonpasteurized ones (Table 2). No significant difference $(P=0.12)$ was observed for STP between

Table 2. Colostrum and milk bacteriology parameters before and after heat treatment ${ }^{1,2}$

\begin{tabular}{lccl}
\hline & \multicolumn{2}{c}{ Treatment group } & \\
\cline { 2 - 3 } Parameter $^{3}(\log 10 \mathrm{cfu} / \mathrm{mL})$ & Raw & Heat-treated & $P$-value \\
\hline Colostrum & & & \\
TPC & $7.43 \pm 0.42^{\mathrm{a}}$ & $6.55 \pm 0.41^{\mathrm{b}}$ & $<0.001$ \\
TCC & $6.15 \pm 0.34^{\mathrm{a}}$ & $5.90 \pm 0.28^{\mathrm{b}}$ & $<0.001$ \\
Milk & & & \\
TPC & $6.60 \pm 0.64^{\mathrm{a}}$ & $4.80 \pm 0.39^{\mathrm{b}}$ & $<0.001$ \\
TCC & $4.88 \pm 1.10^{\mathrm{a}}$ & $2.53 \pm 0.33^{\mathrm{b}}$ & $<0.001$ \\
\hline
\end{tabular}

${ }^{a, b}$ Values within a row with different superscript letters are significantly different.

${ }^{1}$ Reported values reflect mean $\pm \mathrm{SE}$.

${ }^{2}$ Heat treatment for colostrum: $60^{\circ} \mathrm{C}$ for $60 \mathrm{~min}$; Heat treatment for milk: $63^{\circ} \mathrm{C}$ for $30 \mathrm{~min}$.

${ }^{3} \mathrm{TPC}=$ total plate count; $\mathrm{TCC}=$ total coliform count. 
the NP $(7.27 \pm 0.57 \mathrm{~g} / \mathrm{dL})$ and $\mathrm{P}(7.34 \pm 0.54 \mathrm{~g} / \mathrm{dL})$ groups (Table 1$)$.

\section{Effect of Heat Treatment of Colostrum and Milk on the Health Status of Animals}

Calves from the NP group were at greater risk of illness $(\mathrm{OR}=3.8 ; \mathrm{CI}=2.5-5.8)$ and death $(\mathrm{OR}=2.5$; $\mathrm{CI}=1.39-4.3)$ than calves from $\mathrm{P}$ group during the first $21 \mathrm{~d}$ of life. Thus, pasteurization of colostrum with a density $\geq 1,065$ and milk significantly decreased the morbidity $(P<0.0001)$ and mortality $(P<0.001)$ in comparison with calves receiving nonpasteurized colostrum and milk (Table 2). However, the distribution of the cause of illness or death was not significantly different $(P>0.05)$ between the NP and $\mathrm{P}$ groups during the first $21 \mathrm{~d}$ of life (Table 1). The proportion of diseased or dead calves were not significantly affected by STP in either the NP $(P>0.05)$ or in the $\mathrm{P}$ groups $(P>$ $0.05)$ in the range of values studied. Pasteurization was the only significant variable in a multivariate logistic regression analysis on death $(P=0.002)$ and illness in calves $(P<0.0001)$ without observing a significant interaction $(P>0.05)$ with STP.

\section{DISCUSSION}

Colostrum with density $\geq 1,065$ and milk pasteurization improve health status and decrease mortality during the first $21 \mathrm{~d}$ of life in neonatal calves receiving appropriate colostrum ingestion (STP $\geq 5,8 \mathrm{~g} / \mathrm{dL}$ ).

\section{Effect of Heat Treatment on STP and Bacterial Counts}

Measurement of STP by refractometer is a good descriptive marker to estimate the amount of immunoglobulins in neonatal calf serum with the goal of assessing the calf passive immunity transfer after colostrum ingestion (Tyler et al., 1996; Donovan et al., 1998). It has been described that STP values above $5.2 \mathrm{~g} / \mathrm{dL}$ are linked with appropriate passive immunity transfer (Tyler et al., 1996; Calloway et al., 2002). Previous studies have concluded that animals fed colostrum heat treated at $60^{\circ} \mathrm{C}$ for 30 to $60 \mathrm{~min}$ had significantly greater STP when compared with calves fed with raw colostrum (Johnson et al., 2007; Gelsinger et al., 2014); thus, colostrum pasteurization seems to be a good tool to increase the STP in calves. However, we did not detect significant differences in STP between NP and P calves in the current study. In our case, it must be taken into account that we are only including a calf population fed high-quality colostrum (density $\geq 1,065$ ) and showing high STP values (cut-off $\geq 5.8 \mathrm{~g} / \mathrm{dL}$ ). Thus, it seems that the pasteurization process is unable to increase the STP value in calves receiving appropriate colostrum ingestion, as suggested in previous studies (Gelsinger et al., 2014). What our study did find, as expected, is that heat treatment of raw colostrum and milk can reduce the number of pathogens as previously described (Godden et al., 2006; McMartin et al., 2006; Johnson et al., 2007). The exposure of calves to pathogenic bacteria via colostrum and milk could cause diseases, such as diarrhea or septicemia, and facilitate the transmission of microorganisms, such as Mycoplasma spp., M. avium ssp. paratuberculosis, fecal coliforms, and Salmonella spp. (Jayarao et al., 2004; Godden, 2008). Fortunately, feeding pasteurized colostrum and milk can be helpful to reduce fecal-oral transmission of pathogens (Godden et al., 2003; Jayarao et al., 2004; McGuirk and Collins, 2004).

\section{Effect of Heat Treatment on the Health Status of Animals}

Although neonatal calf diseases are multifactorial (Lorenz et al., 2011; Al Mawly et al., 2015), a proper quantity of good-quality colostrum and milk intake is essential to control them (Meganck et al., 2014). Other factors that could alter the prevalence of neonatal calf diseases are individual farm management practices and the preventive medicine programs applied to each farm. The current study, designed to test the potential benefit of pasteurization when calves are fed high-quality colostrum, was carried out within the same farm to reduce interfarm variability (Mac Farlane et al., 2015). With this design, the internal validity of the current is sound because potential confounding factors have been greatly minimized. The current study was carried out on a conventional Spanish dairy farm using Holstein cows and standard operation procedures. Even with these factors in mind, the external validity of our study could be limited mainly because it was carried out in a single farm. For this reason, it would be advisable to have similar studies carried out in other farms with differences in terms of management and facilities.

In our study, we observed a similar reduction in terms of morbidity $(9.8 \%)$ and mortality $(3.7 \%)$ in calves fed pasteurized colostrum and milk in comparison with animals receiving nonpasteurized colostrum and milk during the first $21 \mathrm{~d}$ of life. As reported by Godden et al. (2005), dairy calves fed pasteurized nonsaleable milk have lower morbidity and mortality rates (11.6 and $2.2 \%$, respectively) than calves fed milk replacer (32.1 and $12.1 \%$, respectively). In the same study, calves fed with milk replacer had a higher risk for treatment during summer and winter months $(\mathrm{OR}=3.99)$ as well as death during winter $(\mathrm{OR}=29.81)$ than calves fed 
pasteurized nonsaleable milk. Godden et al. (2012) also reported a significant increase in risk for treatment of $\mathrm{NCD}$ in calves fed fresh colostrum $(\mathrm{OR}=1.32) \mathrm{com}-$ pared with calves fed colostrum heat-treated at $60^{\circ} \mathrm{C}$ for $60 \mathrm{~min}(16.5 \%)$ during the preweaning period.

Finally, the cause of illness or death was not significantly different between the NP and $\mathrm{P}$ groups during the first $21 \mathrm{~d}$ of life in our study, but the difference in mortality between the NP and $\mathrm{P}$ groups was 8.3 and $10.6 \%$ for NCD and other causes, respectively (Table 1). Obviously, this difference is biologically relevant although a significant difference was not observed. A plausible explanation for this apparent contradiction could be that our study has a low statistical potency to detect differences in causes of illness or death and consequently increase the probability to have a type 2 error. Additional studies are necessary to tackle this question.

Curiously, the clinical improvement observed in our study cannot be explained by a significant increase of STP in calves receiving pasteurized colostrum and milk versus calves receiving raw feed. Our study paves the way to carry out additional studies to decipher the mechanisms involved in improving health status in calves receiving pasteurized colostrum and milk. Several research lines can be explored, such as whether pasteurization can have a positive effect on the calf gut microbiota or on the absorption of cellular immunity. It must be taken into account that the positive effect of colostrum is relevant not only during the neonatal phase of life but also during the whole productive life of animals. (Robison et al., 1988; DeNise et al., 1989; Wells et al., 1996; Donovan et al., 1998; Weaver et al., 2000; Faber et al., 2005).

\section{CONCLUSIONS}

Pasteurization of colostrum (density $\geq 1,065$ ) and milk significantly improves calf health status and reduces morbidity and mortality during the first 3 wk of life, even in calves with STP values $\geq 5.8 \mathrm{~g} / \mathrm{dL}$.

\section{ACKNOWLEDGMENTS}

The authors are grateful to Carolina Naranjo Freixa (Idexx Laboratories, Barcelona, Spain) for helping in the review of the article and to the owners of Granja Galacgi (Almacelles, Lleida, Spain) for their time and interest.

\section{REFERENCES}

Al Mawly, J., A. Grinberg, D. Prattley, J. Moffat, J. Marshall, and N. French. 2015. Risk factors for neonatal calf diarrhoea and entero- pathogen shedding in New Zealand dairy farms. Vet. J. 203:155160.

Baintner, K. 2007. Transmission of antibodies from mother to young: Evolutionary strategies in a proteolytic environenment. Vet. Immunol. Immunopathol. 117:153-161.

Berchtold, J. 2009. Bovine neonatology. treatment of calf diarrhea: Intravenous fluid therapy. Vet. Clin. North Am. Food Anim. Pract. 25:73-99.

Butler, J. A., S. A. Sickles, C. J. Johanns, and R. F. Rosenbusch 2000. Pasteurization of discard mycoplasma mastitic milk used to feed calves: Thermal effects on various mycoplasma. J. Dairy Sci. $83: 2285-2288$

Calloway, C. D., J. W. Tyler, R. K. Tessman, D. Hostetler, and J. Holle. 2002. Comparison of refractometers and test endpoints in the measurement of serum protein concentration to assess passive transfer status in calves. J. Am. Vet. Med. Assoc. 221:1605-1608.

DeNise, S. K., J. D. Robison, G. H. Stott, and D. V. Armstrong. 1989 Effects of passive immunity on subsequent production in dairy heifers. J. Dairy Sci. 72:552-554.

Donovan, G. A., I. R. Dohoo, D. M. Montgomery, and F. L. Bennett. 1998. Associations between passive immunity and morbidity and mortality in dairy heifers in Florida, USA. Prev. Vet. Med. 34:31-46.

Faber, S. N., N. E. Faber, T. C. McCauley, and R. L. Ax. 2005. Effects of colostrum ingestion on lactational performance. Prof. Anim. Sci. 21:420-425.

Fleenor, W. A., and G. H. Stott. 1980. Hydrometer test for estimation of immunoglobulin concentration in bovine colostrum. J. Dairy Sci. 63:973-977.

Gelsinger, S. L., S. M. Gray, C. M. Jones, and A. J. Heinrichs. 2014 Heat treatment of colostrum increases immunoglobulin G absorption efficiency in high-, medium-, and low-quality colostrum. J. Dairy Sci. 97:2355-2360.

Godden, S. 2008. Colostrum management for dairy calves. Vet. Clin. Food. Anim. 24:19-39.

Godden, S., S. McMartin, J. Feirtag, R. Stabel, R. Bey, S. Goyal, L. Metzger, J. Fetrow, S. J. Wells, and H. Chester-Jones. 2006. Heat treatment of bovine colostrum II: Effects of heating duration on pathogen viability and immunoglobulin G. J. Dairy Sci. 89:3476-3483

Godden, S. M., S. Smith, J. M. Feirtag, L. R. Green, S. J. Wells, and J P. Fetrow. 2003. Effect of on-farm commercial batch pasteurization of colostrum on colostrum and serum immunoglobulin concentrations in dairy calves. J. Dairy Sci. 86:1503-1512.

Godden, S. M. D. J. Smolenski, M. Donahue, J. M. Oakes, R. Bey, S. Wells, S. Sreevatsan, J. Stabel, and J. Fetrow. 2012. Heat-treated colostrum and reduced morbidity in preweaned dairy calves: Results of a randomized trial and examination of mechanisms of effectiveness. J. Dairy Sci. 95:4029-4040.

Heinrichs, J. A., and A. J. Elizondo-Salazar. 2008. Reducing failure of passive immunoglobulin transfer in dairy calves. Rev. Med. Vet. 160:8-9., 436-440.

Jamaluddin, A. A., D. W. Hird, M. C. Thurmond, and T. E. Carpenter. 1996. Effect of preweaning feeding of pasteurized and nonpasteurized milk on postweaning weight gain of heifer calves on a Californian dairy. Prev. Vet. Med. 28:91-99.

James, R. E., C. E. Polan, and K. A. Cummins. 1981. Influence of administered indigenous microorganisms on uptake of [iodine-125] gammaglobulin in vivo by intestinal segments of neonatal calves. J. Dairy Sci. 64:52-61.

Jayarao, B. M., S. R. Pillai, A. A. Sawant, D. R. Wolfgang, and N. V. Hegde. 2004. Guidelines for monitoring bulk tank milk somatic cell and bacterial counts. J. Dairy Sci. 87:3561-3573.

Johnson, J. L., S. M. Godden, T. Molitor, T. Ames, and D. Hagman. 2007. Effects of feeding heat-treated colostrum on passive transfer of immune and nutritional parameters in neonatal dairy calves. J. Dairy Sci. 90:5189-5198.

Larson, L. L., F. G. Owen, J. L. Albright, R. D. Appleman, R. C. Lamb, and L. D. Muller. 1977. Guidelines toward more uniformity in measuring and reporting calf experimental data. J. Dairy Sci. 60:989-991. 
Lorenz, I., B. Earley, J. Gilmore, I. Hogan, E. Kennedy, and S. J. More. 2011. Calf health from birth to weaning. III. Housing and management of calf pneumonia. Ir. Vet. J. 64:14.

MacFarlane, J. A., D. H. Grove-White, M. D. Royal, and R. F. Smith. 2015. Identification and quantification of factors affecting neonatal immunological transfer in dairy calves in the UK. Vet. Rec. 176:625.

McGuirk, S. M., and M. Collins. 2004. Managing the production, storage and delivery of colostrum. Vet. Clin. North Am. Food Anim. Pract. 20:593-603.

McMartin, S., S. Godden, L. Metzger, J. Feirtag, R. Bey, J. R. Stabel, S. Goyal, J. Fetrow, S. J. Wells, and H. Chester-Jones. 2006. Heattreatment of bovine colostrum I: Effects of temperature on viscosity and immunoglobulin G. J. Dairy Sci. 89:2110-2118.

Meganck, V., G. Geert Hoflack, and G. Opsomer. 2014. Advances in prevention and therapy of neonatal dairy calf diarrhoea: A systematical review with emphasis on colostrum management and fluid therapy. Acta Vet. Scand. 56:75.

Meylan, M., D. M. Rings, W. P. Shulaw, J. J. Kowalski, S. BechNielsen, and G. F. Hoffsis. 1996. Survival of Mycobacterium paratuberculosis and preservation of immunoglobulin $\mathrm{G}$ in bovine colostrum under experimental conditions simulating pasteurization. Am. J. Vet. Res. 57:1580-1585.

Pardon, B., J. Alliët, R. Booneb, S. Roelandt, B. Valgaerena, and P. Depreza. 2015. Prediction of respiratory disease and diarrhea in veal calves based on immunoglobulin levels and the serostatus for respiratory pathogens measured at arrival. Prev. Vet. Med. 120:169-176.

Richter, J., and R. Götze. 1993. Tiergeburtshilfe. 4th ed. Verlag Paul Parey, Berlin and Hamburg, Germany.

Robison, J. D., G. H. Stott, and S. K. DeNise. 1988. Effects of passive immunity on growth and survival in the dairy heifer. J. Dairy Sci. 71:1283-1287.

Smith, B. P., D. G. Oliver, P. Singh, G. Dilling, P. A. Martin, B. P. Ram, L. S. Jang, N. Sharkov, J. S. Orsborn, and K. Jacket. 1989.
Detection of Salmonella dublin mammary gland infection in carrier cows, using an enzyme-linked immunosorbent assay for antibody in milk or serum. Am. J. Vet. Res. 50:1352-1360.

Spier, S. J., B. P. Smith, J. S. Cullor, H. J. Olander, L. D. Roden, and G. W. Dilling. 1991. Persistent experimental Salmonella Dublin intramammary infection in dairy cows. J. Vet. Intern. Med. 5:341-350.

Stabel, J. R., S. Hurd, L. Calvente, and R. F. Rosenbusch. 2004. Destruction of Mycobacterium paratuberculosis, Salmonella spp., and Mycoplasma spp. in raw milk by a commercial on-farm hightemperature, short-time pasteurizer. J. Dairy Sci. 87:2177-2183.

Streeter, R. N., G. F. Hoffsis, S. Bech-Nielsen, W. P. Shulaw, and D. M. Rings. 1995. Isolation of Mycobacterium paratuberculosis from colostrum and milk of subclinically infected cows. Am. J. Vet. Res. $56: 1322-1324$.

Sweeney, R. W. 1996. Transmission of paratuberculosis. Vet. Clin. North Am. Food Anim. Pract. 12:305-312.

Tyler, J. W.. D. D. Hancock, S. M. Parish, D. E. Rea, T. E. Besser, S. G. Sanders, and L. K. Wilson. 1996. Evaluation of 3 assays for failure of passive transfer in calves. J. Vet. Intern. Med. 10:304-307.

Virtala, A. M., Y. T. Gröhn, D. D. Mechor, and H. N. Erb. 1999. The effect of maternally derived immunoglobulin $\mathrm{G}$ on the risk of respiratory disease in heifers during the first 3 months of life. Prev. Vet. Med. 39:25-37.

Weaver, D. M., J. W. Tyler, D. C. VanMetre, D. E. Hostetler, and G. M. Barrington. 2000. Passive transfer of colostral immunoglobulins in calves. J. Vet. Intern. Med. 14:569-577.

Wells, S. J., D. A. Dargatz, and S. L. Ott. 1996. Factors associated with mortality to 21 days of life in dairy heifers in the United States. Prev. Vet. Med. 29:9-19.

Windeyer, M. C., K. E. Leslie, S. M. Godden, D. C. Hodgins, K. D. Lissemore, and S. J. LeBlanc. 2014. Factors associated with morbidity, mortality, and growth of dairy heifer calves up to 3 months of age. Prev. Vet. Med. 113:231-240. 